\title{
Metafora Ganda Yesus Kristus dalam Wahyu 5:5-6: Memahami Penggunaaan Perjanjian Lama dalam Perjanjian Baru
}

\author{
Moses Wibowo ${ }^{1}$, Jonidius Illu², Oren Siregar ${ }^{3}$ \\ 1,2,3Sekolah Tinggi Teologia Injili Arastamar (SETIA) Jakarta \\ 1moseswibowo80@gmail.com, 2joni.illu@gmail.com, ${ }^{3}$ orensiregar@yahoo.com
}

\begin{tabular}{l} 
Article History \\
Received: \\
19 Maret 2021 \\
Revised: \\
12 Mei 2021 \\
Accepted: \\
14 Mei 2021 \\
\hline Keywords \\
(Kata kunci): \\
Jesus Christ; \\
lion and lamb; \\
metaphor; \\
New Testament; \\
Old Testament; \\
violence; \\
metafora; \\
Perjanjian Baru; \\
Perjanjian Lama; \\
singa dan \\
anak domba; \\
Yesus Kristus \\
\end{tabular}

Abstract

The Old and New Testaments are the primary sources of understanding the identity and work of Jesus Christ. There was a consensus from commentators that the combination of the Lion and the Lamb as a double metaphor for Jesus Christ in Revelation 5:5-6 is one of the complex texts and was also crucial to being able to understand the entire book of Revelation. Restrospectively this section has presented multi-interpretation so that it also affects the theological and practical understanding of interpreters. This article will approach the metaphorical combination in Revelation 5:5-6 biblically primarily by dividing the interpretation steps in accordance with the New Testament use of the Old Testament. This point in the book of Revelation is related to the identity and work of Jesus Christ in order to carry out the divine dual mission: judgment and salvation, to establish the kingdom of God on earth through love and not through violence.

\begin{abstract}
Abstrak
Perjanjian Lama (PL) dan Perjanjian Baru (PB) adalah sumber utama dalam memahami identitas dan karya Yesus Kristus. Terdapat konsensus dari para penafsir bahwa kombinasi Singa dan Anak domba sebagai metafora ganda bagi Yesus Kristus dalam Wahyu 5:5-6 adalah salah satu teks kompleks dan juga krusial untuk dapat memahami keseluruhan kitab Wahyu. Secara restropektif bagian ini telah menghadirkan multi interpretasi sehingga juga mempengaruhi pemahaman teologis dan praktis para penafsir. Artikel ini akan mendekati kombinasi metafora dalam Wahyu 5:5-6 secara biblikal terutama dengan menerapkan langkah-langkah penafsiran dalam relasi dengan PB menggunakan PL. Bahwa pokok ini dalam kitab Wahyu direlasikan dengan identitas dan karya Yesus Kristus dalam rangka melaksanakan misi ganda ilahi: penghakiman dan keselamatan, untuk menegakkan kerajaan Allah di bumi melalui kasih dan bukan melalui kekerasan.
\end{abstract}

\section{Pendahuluan}

Diskusi tentang Yesus Kristus selalu menjadi bagian yang aktual sampai sekarang ini. ${ }^{1}$ Kristologi sendiri merupakan bagian central dari kekeristenan. Karena Kristologi adalah bagian yang fundamental dalam iman Kristen. Problematika sentral dalam Kristologi adalah tentang natur Yesus Kristus sebagai Juruselamat yang dinyatakan di dalam indentitas dan karya-Nya. ${ }^{2}$ Sebagai

\footnotetext{
${ }^{1}$ Robert Morgan, "Philip Pullman's Jesus and 'Christ' - and God?," The Expository Times (January 8, 2021): 001452462098371, http://journals.sagepub.com/doi/10.1177/0014524620983714.

${ }^{2}$ Yohanes Verdianto, “Ontologi Kristus Dan Hubungannya Dengan Soteriologi," EPIGRAPHE: Jurnal Teologi dan Pelayanan Kristiani 4, no. 2 (December 1, 2020): 273, http://www.stttorsina.ac.id/jurnal/index.php/epigraphe/article/view/200.
} 
orang percaya kepada Yesus Kristus terus ditantang untuk dapat mengkomunikasikan karya-Nya di tengah dunia yang prularistik secara religius ini. ${ }^{3}$ Fondasi iman Kristen sendiri dibagun atas dasar pengakuan kepada Alkitab sebagai firman Allah yang terdiri dari Perjanjian Lama (PL) dan Perjanjian Baru (PB) sebagai kesatuan yang utuh dan korehen. Pengajaran tentang Yesus Kristus sendiri menjadikan Alkitab sumber pengetahuan dan pengenalan akan Yesus Kristus dan khususnya adalah PB.

Namun demikian PL memiliki peran penting dalam tulisan-tulisan PB. Dari 27 tujuh kitab dalam PB, kitab Wahyu lebih banyak dari semua tulisan PB dalam menggunakan PL. Beale dan Sean mengatakan: "No other book of the NT is as permeated by the OT as is Relevation."4 Akan tetapi belum ada konsensus dari para ahli tentang berapa jumlah pasti bagian PL yang digunakan dalam kitab Wahyu (UBS ${ }^{3}: 394$; NA ${ }^{26}$ : 635; Hühn: 455; Dittmar:195; Swete: 275: Charles: 226). ${ }^{5}$ Fakta ini menjadi tantangan bagi penafsir kitab Wahyu. Setiap penafsir harus memberi perhatian khusus terhadap problem umum kitab Wahyu (penulis, tahun penulisan, genre). Kitab Wahyu diakui sebagai kitab yang sulit dipahami dan ditafsirkan karena keunikan genre kitab Wahyu yang mengkombinasikan tiga genre: apokaliptik, nubuatan dan surat. Disamping itu, juga harus mempelajari bagian-bagian PL yang diacu oleh penulis kitab Wahyu.

Dari fakta ini, maka kitab Wahyu relevan untuk menjadi contoh untuk memahami PB dalam memakai PL. Berkaitan dengan kitab Wahyu akan memilih salah satu bagian yaitu tentang penggunaan metafora ganda yaitu Singa dan Anak domba bagi Yesus Kristus dalam Wahyu 5: 5-6. Yesus Kristus dalam bagian pasal 5:5 ini disebut sebagai singa dari suku Yehuda, tunas Daud sebagai jawaban atas tangisan Yohanes tentang siapa yang sanggup membuka gulungan kitab yang telah termeterai. Namun demikian ada sesuatu yang unik ternyata pada pasal 5:6 yang muncul bukanlah singa tersebut tetapi "seekor Anak domba seperti telah disembelih." Teks ini menunjukkan adanya kombinasi dalam metarofa ganda yaitu singa dan Anak domba bagi Yesus Kristus. Singa dan anak domba sendiri banyak ditemukan dalam tulisan PL, baik digunakan sebagai sesuatu yang riil kepada seekor binatang dan juga secara metafora. Demikian juga dalam PB. Secara spesial Anak domba cenderung diidentifikasi sebagai Yesus Kristus (Kitab Wahyu; Yoh. 1:29; 1 Kor. 5:7; 1 Pet.1:19) tetapi Singa yang diindetifikasi sebagai Yesus Kristus juga bisa diindentifikasi sebagai Iblis atau orang yang jahat (2Tim. 4:17; Ibr. 11:33; 1Pet. 5:8).

Artikel ini bertujuan untuk menjelaskan kitab Wahyu 5:5-6 sebagai bagian tulisan PB dalam penggunakan PL dalam relasi Kristologi kitab Wahyu. Bahwa Yesus Kristus adalah Juruselamat yang berdaulat dan memilih menggunakan "kasih" dari pada "kekerasan" untuk menyatakan keadilan-Nya dalam menyelamatkan dunia dan segala isinya dari perbudakan dosa dan akibatnya. Untuk mencapai tujuan ini maka ada beberapa langkah yang dilakukan. Pertama, menjelaskan tentang bagaimana penulis PB secara umum menggunakan PL. Kedua, mendeskripsikan tentang bagaimana penulis kitab Wahyu menggunakan PL, khususnya Wahyu 5: 5-6 sebagai modelnya. Ketiga, menjelaskan signifikansi kombinasi metafora ganda singa dan Anak

\footnotetext{
${ }^{3}$ Roger Gaikwad, "A Reconsideration of the Significance of the Death of Jesus Christ in the Context of Religious Plurality," Transformation: An International Journal of Holistic Mission Studies 36, no. 1 (January 2 , 2019): 20-28, http://journals.sagepub.com/doi/10.1177/0265378819831844.

${ }^{4}$ G.K. Beale and Sean M. McDonough, "Revelation," in Commentary on the New Testament Use of the Old Testament, ed. G.K. Beale and D.A. Carson (Grand Rapids: Baker Academic, 2007), 1081-1158.

${ }^{5}$ Grant R. Osrborne, "Recent Trend in the Study of the Apocalypse," in The Face of New Testament Studies: A Survey of Recent Research, ed. Scot McKnignt and Grant R. Osborne (Grand Rapids: Baker Academic, 2004), 473-504. Lihat juga: Beale and McDonough, "Revelation."
} 
domba bagi Yesus Kristus dalam Wahyu 5,5-6 dalam relasi memahami Kristologi menurut kitab Wahyu dan mengimplementasikannya dalam kehidupan kontemporer.

\section{Metode Penelitian}

Metode yang digunakan adalah metode kualitatif melalui mengeksplorasi permasalahan, mengumpulkan, menganalisis data ${ }^{6}$ melalui pendekatan biblikal eksegesis. Wahyu 5:5-6 akan didekati dengan pendekatan eksegesis jenis struktrur tafsiran. Pendekatan ini bergerak dari bagian dari ayat ke ayat dengan menyajikan wawasan eksegesis yang relevan pada suatu perikop tertentu dengan mendiskusikan beberapa elemen; sejarah, kultur, redaksional, gramatikal, lesikal dan beberapa tipe dari suatu penelitian eksegesis. ${ }^{7}$ Eksegesis adalah metode untuk menemukan dan memahami pesan dari sang penulis teks. ${ }^{8}$ Ini adalah usaha menginvestigasi teks dalam konteks historisnya. ${ }^{9}$ Terdapat konsensus bahwa penulis PB menggunakan PL untuk beberapa hal utama: apologetik, moral, doktrinal, pedogikal dan liturgikal. Oleh karena itu diperlukan pedoman untuk memahami penggunaan PL dalam PB. Salah satunya adalah dengan menggunakan kriteria pertanyaan dasar sehingga dapat menemukan makna yang benar dan tepat. ${ }^{10}$

\section{Pembahasan}

\section{Problem Umum Memahami Perjanjian Lama dalam Perjanjian Baru}

Secara umum terdapat kesepakatan tentang bagaimana memahami PB dalam menggunakan Kitab PL. Terdapat beberapa varian penggunakan PL dalam PB; mengutip secara langsung; ${ }^{11}$ menyinggung secara tidak langsung atau gema dari Kitab PL. ${ }^{12}$ Dari varian ini sudah memunculkan komfleksitas. Varian utama adalah kutipan (quoted) dan menyebut atau alusi-gema (alluded-echo) bagian PL. Biasanya formula khusus yang dipakai ketika penulis PB mengutip PL “ada tertulis" (Luk. 24:26,49; bdk. Maz. 22; Yes. 52:13-53:12; Yeh. 4:1-8). ${ }^{13}$ Kemudian, "sesuai Kitab Suci" (1 Kor. 15:3-4)"14 atau tanpa hal ini, misalnya, ketika mereka menyebut atau menyingung PL penulis mengunakan satu atau dua kata di dalam sebuah parafrasa tulisan mereka. ${ }^{15}$ Maka diperlukan pemahaman yang baik tentang PL.

\footnotetext{
${ }^{6}$ John Creswell, Riset Pendidikan: Perencanaan, Pelaksanaan, Dan Evaluasi Riset Kualitatif \& Kuantitatif, Edisi 5. (Yogjakarta: Pustaka Pelajar, 2015). 31.

${ }^{7}$ Kevin Gary Smith, Writing and Research: A Guide for Theological Students (UK: Langham Global Library, 2016), 131-137.

${ }^{8}$ Gordon D. Fee, Exegese van Het Nieuwe Testament: Een Praktische Handleiding (Zoetermeer: Boekencentrum, 2007), 7.

${ }^{9}$ Stanley E. Porter and Kent D. Clarke, "What Is Exegesis? An Analysis of Various Definitions," in Handbook to the Exegesis of the New Testament, ed. Stanley E. Porter (Leiden: BRILL, 1997), 3-21.

${ }^{10}$ G.K. Beale and D.A. Carson, "Introduction," in Commentary on the New Testament Use of the Old Testament, ed. G.K. Beale and D.A. Carson (Grand Rapids: Baker Academic, 2007), xxiii-xxviii. Lihat juga:G.K. Beale, Handbook on the New Testament Use of Old Testamaent: Exegesis and Interpretation (Grand Rapids: Baker Academic, 2012).

${ }^{11}$ Lihat: Lukas 3: 3-6; bdk. Yes.40: 3-5; Maz. 22:1; bdk. Mrk. 15:34, ringkasan sejarah dan pengajaran dari PL; Kis. 13:16-41; 1 Kor. 10:1-13; Wahyu, jenis-adegan (motif, tema: Kej. 16:7-13; 18:1-15; Hak. 13,3-20; bdk. Mat. 1:20-21; Luk. 1:11-20, 26-27; 2:9-12; Yoh. 4:1-42; bdk. Kej. 24:10-61; 29:1-20; Kel. 2:16-22.

${ }^{12}$ Lihat: 1 Korintus 11:7-10; bdk. Kej.1-2.

${ }^{13}$ Craig A. Evans, "The Old Testament in the New," in The Face of New Testament Studies: A Survey of Recent Research, ed. Scot McKnight and Grant R. Osborne (Grand Rapids: Baker Academic, 2004), 130-145. Lihat Lukas 3:3-6; bdk. Yesaya 40:3-5. Lukas mengikuti LXX walau tidak secara absolut.

${ }^{14}$ Richrad B. Hays and Joel B. Green, "The Use of the Old Testament by New Testament Writers," in Hearing the New Testament:Srategies for Interpretation (Grand Rapids: William B. Eerdmans, 2010), 122-139.

${ }^{15}$ Evans, "The Old Testament in the New,"130.
} 
PL adalah "Kitab Ibrani", atau "Kitab Suci Ibrani”, yang pada pertengahan abad pertama disebut "Kitab Suci". Namun, ternyata banyak orang Kristen perdana lebih banyak memakai Septuaginta (LXX) dari pada Kitab suci Ibrani (bahasa Ibrani). Faktanya, penulis PB lebih sering mengutip dari LXX. Fakta lain adalah penulis PB telah mengutip PL dari Kitab Suci Ibrani versi Masoretik Teks. Kitab suci ini mungkin juga telah dipengaruhi oleh targum yaitu suatu tradisi targumik yang merupakan interpretasi dari Kitab Suci Ibrani dalam bahasa Aram untuk tujuan mengajar dalam Sinagoge. Bahasa Aram pada zaman itu berfungsi sebagai "lingua franca” (Maz. 68:18; bdk. Ef. 4: 8). ${ }^{16}$ Diduga penulis PB dalam menggunakan PL terdapat korelasi dengan gaya eksegesis Yahudi kuno yaitu; Targum, Misdrash, Pesher, Alegori dan Tipologi. ${ }^{17}$

Pertama, Targum. Melihat kanon Kitab Suci sebagai lebih atau kurang tertutup serta fokus pada hal tekstual. Untuk menafsirkan makna teks melalui memparafrasakannya. Melalui parafrasa, teks dan inteprestasi dikombinasikan. Banyak parafrasa dalam PB mengutip PL dan bentuk ini mengacu pada eksegesis Yahudi dan merefleksikan tradisi targumik secara spesifik. ${ }^{18}$ Kedua, Midrash. Berusaha menginterpretasikan yang mengacu pada kata darash yang berarti mencari atau menyelidiki (lih. Yoh. 5:39). Menyelediki ini adalah suatu usaha mengklarifikasi dengan tujuan memperjelas. Kitab suci digunakan untuk menyelidiki dan berkontemplasi sampai jawaban ditemukan. Ada tiga aturan dan ketiganya juga mempengaruhi PB;1) qal wahomer: di mana apa yang benar dalam kasus yang kurang penting akan menjadi benar dalam kasus yang lebih penting (Mat. 7:11; Rm. 5:10). 2) Gereza shawah: "rule of equivalen" di mana bagian yang satu menjelaskan bagian yang lain jika menggunakan kosakata yang umum (Rm. 4:7-8; 11:7-10). 3) Kelal upherat; umum dan spesifik, di mana aturan umum dapat disimpulkan dari sebuah bagian tertentu, dan sebaliknya (Rm. 13:8-10; Gal. 5:14).

Ketiga, Pesher yang berarti mengungkapkan misteri, melihat Kitab suci sebagai misteri yang harus dijelaskan. Dalam taradisi Qumran yang misteri ini diungkap melalui para nabi yang merupakan hamba Allah (1QpHab 7:4-5). Cara seperti ini juga ditemukan dalam PB (Mrk. 12:10-11 mengutip Maz. 118:22-23; Mrk. 14:27 mengutip Za. 13: 7; Kis. 2:17-21 mengutip Yoel 2:28-32). Eksegesis Pesher memahami bagian spesifik Kitab Suci sebagai penggenapan dalam spesifik peristiwa sejarah dan pengalaman. Keempat, Alegori, memberi penekankan pada hal simbolik dan mene-mukan makna. Alegori mengasumsikan bahwa teks bukan peristiwa sejarah atau tanpa makna literal. Dalam Galatia 4: 24-31 menjelaskan bahwa Sara dan Hagar adalah simbol dua perjanjian. Dalam 1 Korintus 10:1-4 menjelaskan bahwa peristiwa penyeberangi laut Teberau adalah simbol baptisan. Kelima, Tipologi. Jenis eksegesis ini masih mempedulikan sejarah, di mana didasarkan pada kepercayaan bahwa sejarah Alkitab (dulu) membawa efek kepada masa sekarang dan mungkin diperbaharui. Masa sekarang ini berada di bawah bayang-bayang sejarah Alkitab. Akan tetapi tipologi bukan tanpa mengacu kepada Alkitab, hal ini berasal atau berakar pada PL sendiri. Peristiwa keluarnya bangsa Israel dari mesir menjadi tipologi kembalinya bangsa Israel dari pembuangan (Yes. 43:16-17. Daud adalah tipologi raja yang benar yang akan merestorasi Israel (Yes. 11:1-3; Yer. 23:5-6; Za. 3:8). Yesus mengkorelasikan penghukuman Sodom dengan datangnya penghakiman eskatologis (Luk.

\footnotetext{
${ }^{16}$ Hays and Green, "The Use of the Old Testament by New Testament Writers," 122.

${ }^{17}$ Evans, "The Old Testament in the New,"131-133.

${ }^{18}$ Misalnya Markus 4,12 dengan Tg. Isa. 6:10; Luk. 6,36 dengan Tg. Ps-J. Lev. 22,28; Rom. 10,6-8 dengan
} Tag. Neof. Deut. 30. 11,14. 
17:28-30). Istri Lot dengan mereka yang kehilangan hidup (Luk. 17:32-33). Dalam PB yang paling banyak mengunakan tipologi adalah Kitab Ibrani.

\section{Problem Khusus dalam Relasi dengan Kitab Wahyu}

Ada problem ketika menafsirkan Kitab Wahyu. Pertama, penulis, tahun penulisan dan genre. Fakta ini menghadirkan beberapa model metode penafsiran, misalnya: Historis, preteris, furutis, idealis. Empat varian ini memiliki kelebihan dan kekurangan. Oleh karena itu para penafsir mengkombinasikan empat model ini sebagai presaposisi mereka dalam menafsir. Tetapi para penafsir tetap memberikan porsi yang lebih besar terhadap salah satu varian. Sebagai contoh Beale memberikan porsi yang lebih besar pada model idealis dan Osbrone memberikan porsi yang lebih besar pada model futuris. Namun dalam artikel ini cenderung untuk mengikuti metode Beale karena ia juga menekankan sejarah keselamatan dalam metode idealisnya.

Kedua, kompleksitas dalam menentukan dan menemukan kutipan, penyebutan atau menyinggung (alusi) dan gema (echo) secara partial dalam bagian yang spesifik. Apa lagi formula seperti "ada tertulis", "Roh Kudus berkata" dan "menurut Kitab Suci" tidak ditemukan dalam Kitab Wahyu. Bahkan penyebutan secara tidak langsung dilakukan oleh penulis Wahyu secara "intertekstual" dan mengkomposisikannya secara bersamaan dalam naratif Kitab Wahyu. ${ }^{19}$ Namun, hasil penelitian Kitab Wahyu memberi informasi bahwa Kitab Wahyu didominasi oleh beberapa literatur dari PL. Penulis Kitab Wahyu menunjuk Kitab Yesaya 46 kali, Daniel 31 kali, Yehezkhiel 29 kali, Mazmur 27 kali, dan juga beberapa bagian juga menyinggung Kitab Kejadian, Ulangan, Yeremia, Yoel dan Zakharia. Beale menduga bahwa Kitab Wahyu lebih dipengaruhi oleh Kitab Daniel, khususnya "midrash pada Daniel 2 dan $7 .{ }^{20}$ Namun demikian belum ada konsensus dari para penafsir tentang jumlah secara pastinya. Para penafsir hanya sepakat bahwa penulis Wahyu menjadikan PL sebagai sumber penting dan menggunakannya secara bebas. Penggunaan PL sebagai sumber secara bebas memunculkan problem yang kompleks dan mengadirkan pertanyaan mendasar, apakah maknanya sama dengan konteks asli di dalam PL?

Ada empat hal utama yang menjadi alasan bagi banyak penafsir bahwa Yohanes tidak terlalu mempedulikan makna dalam konteks aslinya: Pertama, kutipan bernatur informal. Kedua, berpusat pada otoritas penulis dalam konteksnya dalam spirit perspektif nubuatan dari pada konteks PL. Ketiga, secara liguistik juga menjadi petunjuk bahwa Yohanes bebas dan kreatif. Karena kadang kala juga meredefinisi makna aslinya. Keempat, kurangnya bukti bahwa penulis Kitab Wahyu secara sadar menginterprestasikan teks yang ia kutip. Dari empat hal ini disimpulkan bahwa penulis Kitab Wahyu secara kreatif menggunakan PL berdasarkan pemahaman imaginasi pembaca dan dalam konteks yang baru. Ia mentransformasi pengambaran dari PL untuk tujuan teologikal yang diaplikasikan dalam konteks penulis dan pembaca. ${ }^{21}$ Faktanya, muncul problem baru tentang siapa yang paling berpengaruh dalam menentukan makna. Ada yang memberi penekanan pada penulis dan ada yang memberi penekanan pada pembaca. Khusus Kitab Wahyu dan berkaitan dengan metafora penelitian ini mendukung penafsir yang mengabungkan dua elemen ini (Penulis dan pembaca saling melengkapi). Yohanes dalam penggunakan PL sangat sensitif dan setia pada konteks aslinya, tetapi secara bersamaan juga

${ }^{19}$ Osrborne, "Recent Trend in the Study of the Apocalypse," 492. Lihat juga: Hays and Green, "The Use of the Old Testament by New Testament Writers,"129-130.

${ }^{20}$ Grant R. Osrborne, "Recent Trend in the Study of the Apocalypse."492.

${ }^{21}$ Ibid. 493. Contohnya adalah Zakharia 12:10; bdg. Wahyu 1:17. 
secara bebas mentransformasikan ketika mengaplikasikan dalam konteks yang baru yaitu penerima (perspektif intertekstual dan analisis penerima menjadi satu kombinasi).

Wahyu 5:5-6 yang menarasikan tentang metafora singa dan Anak Domba dapat menjadi contoh, di mana penulis Wahyu menjadikan metafora singa dan anak domba dalam PL sebagai rekan dialog. Terutama dalam mengkomunikasikan pemahamannya tentang Yesus Kristus, di imana penulis Kitab Wahyu secara intertektual mengkorelasikan teks PL dan juga dua konteks. Oleh karenanya terjadi dialektikal imajinasi antara dunia PL dan dunia PB yang menghasilkan transformasi dan aplikasi yang baru sebagai suatu implikasi dari penggunakan sumber PL.

\section{Tafsiran Wahyu 5:5-6}

Pada bagian ini akan mengikuti langkah-langkah penafsiran seperti yang telah dijelaskan pada bagian metode penelitian yaitu dengan mengacu kepada 6 kriteria pertanyaan dasar dalam memahami penggunaan PL di dalam PB. Enam kriteria tersebut dalam bagian ini akan dibahas secara simultan jika bagian itu memang terkait antara satu dan lainnya.

\section{Analisis Konteks Teks dan Penerima Wahyu 5:5-6}

Bagian ini akan menjelaskan tentang analisis konteks teks dan penerima Wahyu 5:5-6. Pertama, analisis konteks teks Wahyu 5:5-6. Berdasarkan konteks Wahyu pasal 5, ayat 5 dan 6 merupakan solusi dari problem yang dijelaskan dalam ayat 2-3. Di mana ada pertanyaan dari Malaikat tentang siapakah yang layak membuka gulungan kitab dan melepas meterai? Mengenai gulungan kitab ini terdapat varian identifikasi. Identifikasi pertama, gulungan kitab menunjuk kepada "the lamb's book of life" yang berisi nama-nama orang percaya yang telah dituliskan (Why. 3:5; $13: 8 ; 20: 12,15 ; 21: 27)$. Identifikasi kedua, gulungan kitab juga dapat menunjuk kepada "the book has writing inside and on the back." Karena nama-nama yang telah ditebus yang dituliskan hanya di bagian dalam dari Kitab tersebut. Identifikasi ketiga, gulungan kitab dalam konteks ini bukan hanya menunjuk kepada yang dipilih saja tetapi juga spesial karena direlasikan dengan penghakiman bagi para antikris. Jika memperhatikan PL, misalnya Daniel 7; 12; dan Yehezkhiel 2-3 secara prisipil menekankan pada penghakiman orang yang tidak percaya dan kemudian pada keselamatan bagi umat Allah. Hal ini berelasi dengan gulungan kitab kecil (Why. 10), di mana lebih menekankan pada hal penghakiman dan kemudian peristiwa keselamatan. ${ }^{22}$

Kedua, analisis konteks penerima. Konteks teks Wahyu pasal 4-5 berkorelasi dengan konteks penerima tulisan Yohanes. Konteks yang dimaksud adalah agama-politik pada masa kekaisaran Romawi. Yohanes melukiskan kekaisaran Romawi sebagai pemerintah yang melegalkan kekerasan dan penindasan sebagai sebuah sistem kekaisaran. Sistem ini melegalkan tirani politik dan eksplorasi ekonomi. Hal ini digambarkan oleh Yohanes melalui simbol binatang yang menakutkan dan membahayakan (Why.13; 17;18). Binatang ini mempresentasikan kekuatan militer dan kuasa politik (Pax Romana). Yohanes menarasikan dalam perspektif kuasa penyembahan seperti dalam suatu ibadah (Why. 13: 3-4). Dan kondisi ini membawa penderitaan bagi orang percaya (mati martir, Antipas) karena orang percaya ini beroposisi dengan kekaisaran Romawi dan orang-orang Yahudi. Mereka melawan kedaulatan Allah sehingga mereka adalah pengikut Iblis dan membenci orang percaya (Why. 2:13; 6: 9-10; 11:16; 16:6; 17:6). ${ }^{23}$

${ }^{22}$ G.K. Beale, The Book of Revelation: NIGTC (Grand Rapids: Eerdmans, 1999), 339.

${ }^{23}$ Richard Bauckham, The Theology of The Book of Revelation, New Testament Theology (Cambridge: Cambridge University, 1993)., 35-39. Lihat juga: Laszlo Gallusz, The Throne Motif in the Book of Revelation: Profile from the History of Interpretation (New York: Bloomsbury, 2014)., 100-102, 144-147. 
Secara khusus, metafora singa dan Anak Domba pada ayat 5 dan 6 berfungsi sebagai solusi dari problem pada bagian sebelumnya (Why. 5: 1-4) bahkan kitab Wahyu secara keseluruhan. Problem itu mengenai tentang Yesus yang akan membuka gulungan kitab yang termeterai yang dimetaforakan secara ganda (singa dan Anak Domba). Membuka gulungan yang termeterai juga mengandung makna layak, berdaulat atau berkuasa atas dua peristiwa ganda yaitu penghakiman dan penyelamatan. Secara restrospektif perihal peristiwa ganda ini telah disingkapkan di dalam PL yang direlasikan dengan suatu peristiwa eskatologis. Secara khusus dalam Kitab Wahyu, Yohanes mengungkapkan tentang siapa yang layak dan berdaulat atas peristiwa ganda yang telah disingkapkan dalam PL. Peristiwa ini telah direlasikan dengan adanya suatu peristiwa eskatologis. Yesus Kristus yang dinarasikan melalui metafora ganda merupakan oknum yang layak melaksanakan penghakiman dan penyelamatan. Ia (singa dan Anak Domba) adalah solusi atas problem tersebut (Why. 5:5-6).

Pada ayat 11-14 merupakan reaksi dari solusi ini. Berfungsi sebagai kontras dengan konteks agama-politik pada masa kekaisaran Romawi, di mana mereka berlaku semena-mena kepada orang yang beroposisi dengan mereka, termasuk orang percaya. Mereka seperti binatang buas, termasuk seperti "singa" (Why. 13:2). Pemakaian metafora singa dan Anak Domba dalam Kitab Wahyu sendiri berakar dan berasal dari PL.

\section{Analisis konteks Wahyu 5:5-6 dalam relasi dengan PL sampai dengan PB}

Bagian ini akan secara simultan menjelaskan tentang langkah-langkah penafsiran dalam relasi dengan kriteria kedua, tiga dan keempat. Secara tidak langsung Yohanes menyinggung beberapa tulisan dalam PL ketika ia menggunakan metafora singa yang diidentifikasi berasal dari suku Yehuda yaitu tunas Daud. Namun secara umum, dalam PL, kata singa disebut secara ekplisit lebih dari 150 kali. Walaupun demikian jika dijumlahkan dengan penggunaan kata singa secara implisit terdapat lebih dari 200 kali dan menggunakan beberapa terminologi kata. ${ }^{24}$ Kemudian

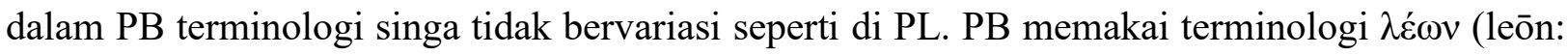
singa) hanya sebanyak 9 kali dan tidak pernah digunakan dalam keempat Injil baik secara literal atau metafora. ${ }^{25}$ Dari semua varian kata dan konteks pemakaian, penggunakan metafora singa dalam PL dan PB telah digunakan dalam perspektif positif dan negatif. Metafora singa dalam PL selalu memiliki fungsi negatif dan positif. Negatif, singa selalu menakutkan, membahayakan bagi yang beroposisi dengan dia (the outsider group). Positif, singa menunjuk kepada fungsi perlindungan bagi yang tidak beroposisi dengannya (the insider group) dan tetap terdapat kesan adanya kekerasan.

Demikian pula dengan pemakaian metafora singa dalam PB bisa menunjuk kepada Iblis yaitu pribadi yang jahat, mahkluk supranatural yang baik dan jahat, figur Mesias-Yesus dan musuh orang yang benar dan setia. Dari data ini, menunjukkan bahwa pemakaian metafora singa dalam PB memiliki fungsi bervariasi. Walaupun demikian ada kesamaan dengan PL yaitu pada hal yang positif dan negatif. Namun secara data, singa dalam PB cenderung digunakan untuk menggambarkan perihal negatif dari pada positif. Singa juga tidak bisa dilepaskan dari kesan tindakan kekerasan atau membahayakan. Singa dalam ayat 5 diperjelas sebagai singa dari suku Yehuda, tunas Daud, telah menang dan layak membuka gulungan Kitab dan meterai. Singa dari suku Yehuda mengacu pada kejadian 49:9 dan tunas Daud mengacu pada Yesaya 11:1-5:10

\footnotetext{
${ }^{24}$ Brent A. Strawn, What Is Stronger than a Lion?: Leonine Image and Metaphor in the Hebrew Bible and the Ancient Near East (Göttingen: Vandenhoeck \& Ruprecht, 2005)., 26, 293-356.

${ }^{25}$ Lihat 2 Timotius 4: 17; Ibr. 11:33; 1 Ptr. 5:8; Why. 4:7; 5:5; 9:8,17; 10:3;13:2.
} 
(Bdk. Yer. 11:19; 23:5; 33:15; Za. 3:8). Bagian-bagian Ini menunjuk kepada figur Mesias yaitu Kristus.

Kemudian bagaimana dua bagian PL atau sumber ini ditangani atau ditanggapi dalam literatur dari masa bait Allah bangsa Yahudi yang kedua? Pertama, dua bagian ini (Kej. 49:9 dan Yes. 11:1-5,10) juga merupakan bagian penting dari pengharapan akan Mesias dalam tradisi dan literatur Yahudi. Dimana Mesias akan menjadi raja yang duduk ditahta Daud dan juga menunjuk kekuatan militer yang kuat. Sehingga kombinasi singa dari suku Yehuda dan tunas Daud menekanan akan hadirnya Daud baru yang menang atas para musuh Israel. ${ }^{26}$ Nuansa ini

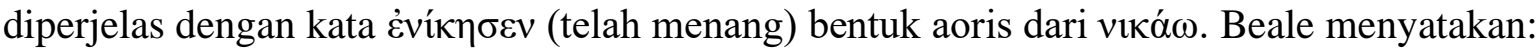

vikác (overcome) serves as an introduction to the these OT titles and brings out their "conquering" significance, since both concern the prophecy of a mesianic figure who will overcome his enemy through judgment...This notion may be highlighted by understanding

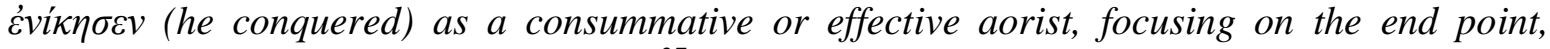
accomplishment, or climax of the action. ${ }^{27}$

Tentu, hal ini berkorelasi dengan harapan Yohanes kepada ketujuh jemaat pada pasal 2-3 supaya mereka juga menjadi pemenang karena Yesus telah menang sehingga mereka layak menerima hadiah dari Allah. Oleh karena itu Yesus Kristus menggenapkan dua nubutan yaitu singa dari suku Yehuda dan tunas Daud serta Dia adalah telah menang. Dia adalah Mesias yang dijanjikan sehingga layak untuk membuka gulungan Kitab yang termeterai. Hal ini menunjuk kepada kedaulatan Allah di dalam Yesus Kristus, tentang rencana ilahi dari karya penebusan dan penghakiman. Bagian ini dilihat sebagai klimaks atau konsumasi karya Kristus. ${ }^{28}$ Dengan demikian metafora singa dalam konteks ini berfungsi secara positif (the insider group) yang diperjelas dengan frasa dari suku Yehuda (perspektif berkat, Kej. 49: 9) dan tunas Daud (Raja yang mejadi hakim yang adil; Yes. 11:1-5:10). Kemudian berfungsi sebagai penegasan tentang indentitas siapa yang layak membuka gulungan Kitab yang telah termeterai. Akan tetapi melalui metafora singa, kesan kekerasan atau kekejaman kepada para musuh tidak bisa hilang (the outsider group, Kej. 49:9; Yes. 11:4) dan oleh karenanya bisa salah dalam memahaminya. ${ }^{29}$ Tetapi juga hal yang logis bagi konteks pada saat itu.

Kedua, Yohanes juga secara tidak langsung menyinggung beberapa bagian PL dan mungkin juga PB ketika menggunakan metafora Anak Domba. Yohanes melihat Anak Domba bukan singa. Tentu hal ini tidak sesuai dengan harapan Yohanes dan merupakan hal unik atau spektakuler. Berkaitan dengan anak domba, dalam PL dan PB diperoleh informasi serta data bahwa pemakian domba sebagai simbolik atau semantik dalam Alkitab begitu kompleks dikarenakan terminologi ini muncul sebanyak 742 kali dalam Alkitab. Kemudian memiliki fungsi yang vital bagi kultur Ibrani yaitu dalam hal: keagamaan, sipil dan kehidupan bangsa Israel. Pemakaian

\footnotetext{
${ }^{26}$ Beale, The Book of Revelation: NIGTC.349. Lihat juga: Laszlo Gallusz, The Throne Motif in the Book of Revelation: Profile from the History of Interpretation. 150; Loren L. Johns, The Lamb Christology of the Apocalypse of John : An Investigation into Its Origins and Rhetorical Force, WUNT,2/167. (Tübingen: Mohr Siebeck, 2003).166.

${ }^{27}$ Beale, The Book of Revelation: NIGTC.349-350.

${ }^{28}$ Ibid. 350.

${ }^{29}$ Lihat: Richard Bauckham, The Climax of Prophecy: Studies in the Book of Relevelation (Edinberugh: T\&T Clark, 1993). 179-183;Brent A. Strawn, "Why Does the Lion Disappear in Revelation 5? Leonine Imagery in Early Jewish and Christian Literatures," Journal for the Study of the Pseudepigrapha 17, no. 1 (September 2007): 37-74, http://journals.sagepub.com/doi/10.1177/0951820707083881. Loren L. Johns, The Lamb Christology of the Apocalypse of John : An Investigation into Its Origins and Rhetorical Force., 166.
} 
"domba" dan "domba muda" atau yang hal seperti ini adalah terbatas tetapi juga tidak menghilangkan kompleksitasnya. ${ }^{30}$ Dalam PL, anak domba berfungsi untuk kepentingan kehidupan bangsa Israel, baik hal jasmani (makanan dan pakian) maupun rohani dalam berelasi dengan Allah yang berkaitan dengan hal pengampunan dosa dalam perspektif pedamaian-eskatologis yang di kemudian hari semakin menjadi jelas dalam PB. Secara restrospektif "anak domba" selalu indentik dengan kelemahan dan berada di bawah bayang-bayang kekuatan yang lebih kuat.

Ketiga, bagaimana faktor tekstual dalam relasi dengan tradisi kitab Ibrani dan Yunani ketika dikutip atau disebut oleh PB? Dalam LXX terminologi yang dipakai untuk anak domba adalah

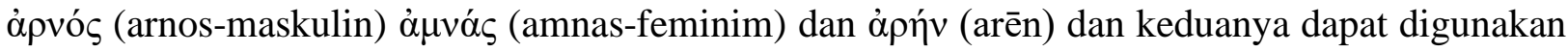

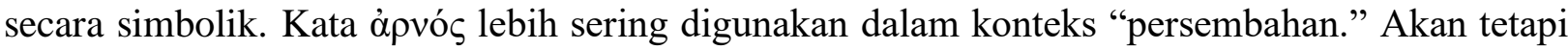
gambaran anak domba sebagai metafora atau simbolik terminologi yang sering dipakai adalah

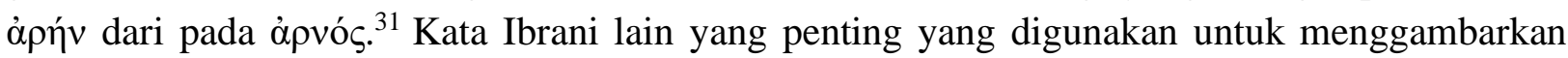
anak domba adalah śeh (ֶָ (śeh). Kata ini 16 kali disebut dalam Alkitab Ibrani, dan menggambarkan domba atau domba sebagai bagian dari kawanan. Dan ini adalah kata yang digunakan untuk anak domba yang diambil untuk disembelih di Yesaya 53. ${ }^{32}$

Keempat, bagaimana PB memakai atau mengaplikasikan PL? Dalam PB, terdapat beberapa

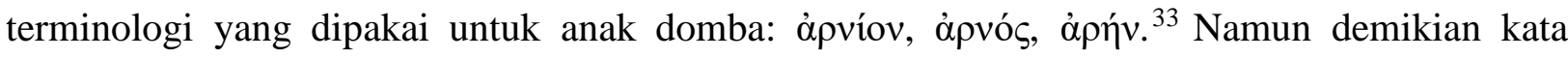
àpvíov (arnion: young sheep, lamb, ram), lebih sering dipakai yaitu sebanyak 30 kali. Satu kali dalam Yohannes 21:15 dengan menggunakan kosakata $\alpha \rho v i ́ \alpha$ dalam kasus akusatif neuter jamak dari á $\rho v i ́ o v$ adalah satu-satunya dalam PB, dan 29 kali dalam Kitab Wahyu. ${ }^{34}$ Kata ápvíov oleh penulis injil Yohanes dan Wahyu digunakan untuk menunjuk pada Yesus Kristus, baik sebagai nama atau metafora dan ini adalah hal yang unik. ${ }^{35} \mathrm{~PB}$ juga menggunakan terminologi kata yang lain bagi anak domba, misalnya ó $\mu$ vò $\varsigma$ dalam PB menggunakannya sebanyak 4 kali (Yoh. 1:29, 35; Kis. 8:32; 1Ptr. 1:19). Dalam Kisah Para Rasul dan 1 Petrus dikorelasikan dengan "korban" dan menunjuk kepada Yesus Kristus. Paulus dalam 1 Koristus 5:7: "Sebab anak domba Paskah kita juga telah disembelih, yaitu Kristus." Juga menggunakan dan menunjuk kepada Yesus kristus, dimana ia mengunakan kata $\pi \alpha ́ \sigma \chi \alpha$ (pascha) yang menunjuk kepada domba paskah secara figuratif. ${ }^{36}$ Kemudian kata $\dot{\alpha} \eta \dot{v}$, kosakata ini hanya digunakan oleh Lukas dalam kasus akusatif, dalam narasi Yesus mengutus murid-murid seperti anak domba di tengah serigala (Luk.

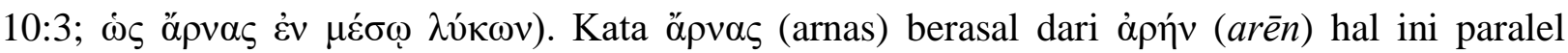

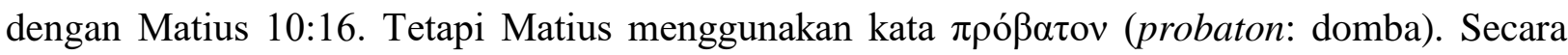

${ }^{30}$ Loren L. Johns, The Lamb Christology of the Apocalypse of John : An Investigation into Its Origins and Rhetorical Force. 28; 207-215.

${ }^{31}$ Ibid. 30-32.

32 Sérgio Monteiro, “The Lion and the Lamb in Revelation 5," accessed February 4, 2021,

file:///E:/ARTIKEL/The_Lion_and_the_Lamb_in_Revelation_5.pdf. Lihat juga: Loren L. Johns, The Lamb Christology of the Apocalypse of John: An Investigation into Its Origins and Rhetorical Force. 29.

${ }^{33}$ Loren L. Johns, The Lamb Christology of the Apocalypse of John : An Investigation into Its Origins and Rhetorical Force.23-28; Sérgio Monteiro, "The Lion and the Lamb in Revelation 5."

${ }^{34}$ Lihat Wahyu 5:6, 8, 12, 12; 6:1, 16; 7:9, 10, 14, 17; 12:11; 13:8, 11; 14:1, 4, 10; 15:3; 17:14; 19:7,9; 21:9, $14,22,23,27 ; 22: 1,3$.

${ }^{35}$ Loren L. Johns, The Lamb Christology of the Apocalypse of John : An Investigation into Its Origins and Rhetorical Force.22; Monteiro, "The Lion and the Lamb in Revelation 5."

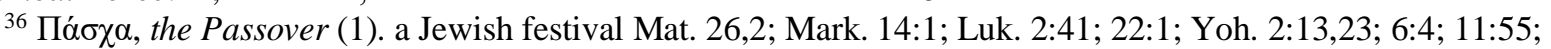
12:1; 13:1; 18:39; 19:14; Kis. 12:4. (2). The Paschal lamb Mat. 26:17; Mark. 14:12,14; Luk. 22:7, 11, 15; Yoh. 18:8. Fig. 1 Kor 5:7. (3). The Passover meal Mat. 26:18; Mark. 14:16; Luk. 22: 8,13; Ibr. 11,28. [paschal]. Lihat juga: Johns, The Lamb Christology of the Apocalypse of John, 25. 
linguistik ảṕ̣v menunjuk kepada domba muda atau kecil namun demikian berdasarkan konteks adalah menunjuk pada anak domba (Lamb) yang rentan dengan bahaya. ${ }^{37}$ Patut diduga bahwa metafora à à $\rho$ víov dalam Kitab Wahyu.

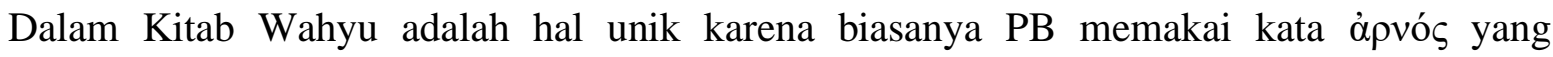
menunjuk pada karya penebusan Kristus. Tetapi dalam Wahyu menggunakan kata ópvíov untuk mengambarkan Kristus yang unik. Dalam Wahyu kata ả pvíov sendiri muncul sebanyak 29 kali dan lebih menunjuk kepada Kristus. Anak domba ini digambarkan berdiri dan berada di tengah tahta diantara keepat binatang dan tua-tua dan didentifikasi bahwa ia seperti telah disembelih, bertanduk tujuh dan bermata tujuh. Secara retrospektif ada tiga kemungkinan berkaitan dengan

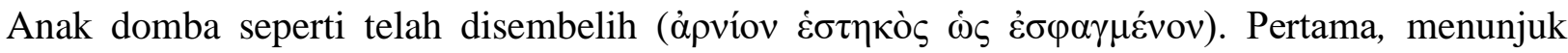
kepada domba paskah sebagai "new exodus" motif (Kel. 12,1-13). Kedua, menunjuk kepada domba yang dibawa ke pembantaian dan diremukkan karena pelanggaran umat-Nya sebagai korban penebus salah (Yes. 53:7-8), di mana menunjuk kepada hamba Yahweh yang menderita yang digenapi dalam penderitaan dan penyaliban Yesus Kristus. Dalam LXX kata yang dipakai untuk domba dalam Yesaya 53 adalah ỏ $\mu v o ́ s$ yang mungkin dan diduga dilatarlarbekangi oleh penggunaan kata טליץ: (talia) dalam bahasa Aram yang berarti anak domba tetapi juga hamba dan anak laki-laki. ${ }^{38}$ Oleh karenanya pengorbanan hamba Yahweh dalam karya penebusan dalam Yesaya 53: 9 adalah sesuai dengan Wahyu 5:9 yang dijelaskan sebagai pribadi yang layak membuka gulungan kitab dan meterai karena Dia telah disembelih. Ketiga, anak domba sebagai "tamidoffer" dalam perspektif liturgi ibadah di Bait Allah.

Dalam konteks Wahyu 5 Anak Domba ini digambarkan bahwa ia berdiri seperti telah disembelih dan bertanduk tujuh, bermata tujuh yang menunjuk kepada Roh Allah. Hal ini digambarkan seperti telah disembelih yang menunjuk kepada konsekuensi atau akibat dari peris-

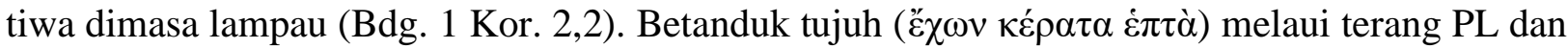

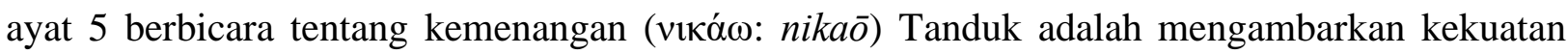
dan tujuh tanduk memiliki signifikansi bahwa anak domba memiliki kekuatan yang mahabesar atau sempurna (tujuh adalah simbol tentang kesempurnaan) yang menunjuk kepada Mesias sang pemenang (Lihat: Ul. 33:17; 1Raj. 22:11; Maz. 89:17; Dan. 7:7-8:24; bdg. 1En. 90:6-12:37). ${ }^{39}$ Bermata tujuh yang menunjuk kepada Roh Allah yang diutus Allah keseluruh bumi (Why. 1:4). Hal ini menunjukkan akan eksistensi kedaulatan Allah sebagai pribadi yang maha hadir (bdk. Za. 3-4; 2 Taw. 16:19), ${ }^{40}$ mahatahu, berkuasa dan berhikmat (1Kor. 1:24). ${ }^{41}$ Bahkan Wahyu 11:1-13 menunjuk pada kuasa Allah yang berdaulat atas kematian dan kehidupan para pengikut Kristus (sumber kuasa dan kehidupan) dan juga berdaulat atas Iblis dan para pengikutnya.

Berdarsarkan uraian di atas terdapat kompleksitas dalam memahami metafora Anak Domba pada ayat 6. Terutama dalam memastikan anak domba yang mana persis dimaksudkan oleh penulis Kitab Wahyu (tiga kemungkinan). Namun dari semua kemungkinan yang ada metafora Anak Domba berfungsi untuk menujukkan indentitas atau menjelaskan pribadi yang layak dan berdaulat yaitu Yesus Kristus. Ia adalah Mesias yang dijanjikan dan diharapkan melalui nu-

\footnotetext{
${ }^{37}$ Ibid. 26-27; 109.

${ }^{38}$ Beale, The Book of Revelation: NIGTC, 351; Gallusz, The Throne Motif in the Book of Revelation, 150-151.

${ }^{39}$ Beale, The Book of Revelation: NIGTC, 351; Gallusz, The Throne Motif in the Book of Revelation, 151.

${ }^{40}$ Beale, The Book of Revelation: NIGTC, 355.

${ }^{41}$ Ibid. 355 dan lihat juga: Jeremy R. Treat, The Crucified King: Atonement and Kingdom in Biblical and Systematic Theology (Grand Rapids: Zondervan, 2014), 125.
} 
buatan dalam PL. Yesus Kristus adalah pribadi yang berdaulat atas penghakiman dan keselamatan dalam misi menyelesaikan masalah dunia yaitu dosa dan akibatnya, bukan dengan kekerasan tetapi dengan kasih ilahi. Ia adalah sang singa dari Yehuda, tunas Daud dan sekaligus juga adalah sang Anak Domba.

\section{Kesimpulan}

Metafora ganda antara singa dan Anak Domba tentang Yesus dalam Wahyu 5:5-6 ketika didekati melalui pendekatan Perjanjian Baru menggunakan Perjanjian Lama memberikan pemahaman tentang identitas dan karya Yesus Kristus. Metafora ganda ini adalah kombinasi yang unik terkait dengan indetitas dan karya Yesus Kristus dalam rangka melaksanakan misi ganda ilahi yaitu penghakiman dan keselamatan. Misi ini adalah untuk menegakkan kerajaan Allah di bumi melalui kasih-Nya yaitu pengorbanan di kayu salib dan bukan melalui kekerasan. Kombinasi ini digunakan secara kontras antara Yesus Kristus dan Iblis oleh Yohanes. Metafora bagi Iblis dalam Kitab Wahyu secara konsisten menggunakan binatang buas sebagai simbol dari perilaku kekerasan, kejam dan jahat. Perilaku ini dikerjakan oleh Iblis dan para pengikutnya terhadap para pengikut Yesus Kristus. Metafora ganda berfungsi untuk menjelaskan status dan kualifikasi Yesus Kristus. Yesus adalah Mesias yang tidak dapat didefinisikan hanya melalui satu metafora saja. Ia adalah pribadi yang berdaulat, penuh keadilan tetapi juga penuh kasih. Kombinasi ini saling melengkapi dan merupakan pengenapan janji dari PL.

Penelitian ini masih perlu dikembangkan dan terus dikaji, misalnya dari sudut teologi praktika. Khususnya secara etis-teologis atau misi dalam relasi dengan identitas dan karya Yesus Kristus dalam Kitab Wahyu, serta melihat bagaimana signifikasinya bagi para pengikut Yesus Kristus pada zaman ini.

\section{Referensi}

Bauckham, Richard. The Climax of Prophecy: Studies in the Book of Relevelation. Edinberugh: T\&T Clark, 1993.

Beale, G.K. Handbook on the New Testament Use of Old Testamaent: Exegesis and Interpretation. Grand Rapids: Baker Academic, 2012.

. The Book of Revelation: NIGTC. Grand Rapids: Eerdmans, 1999.

Beale, G.K., and D.A. Carson. "Introduction." In Commentary on the New Testament Use of the Old Testament, edited by G.K. Beale and D.A. Carson, xxiii-xxviii. Grand Rapids: Baker Academic, 2007.

Beale, G.K., and Sean M. McDonough. "Revelation." In Commentary on the New Testament Use of the Old Testament, edited by G.K. Beale and D.A. Carson, 1081-1158. Grand Rapids: Baker Academic, 2007.

Brent A. Strawn. What Is Stronger than a Lion?: Leonine Image and Metaphor in the Hebrew Bible and the Ancient Near East. Göttingen: Vandenhoeck \& Ruprecht, 2005.

Craig A. Evans. "The Old Testament in the New." In The Face of New Testament Studies: A Survey of Recent Research, edited by Scot McKnight and Grant R. Osborne, 130-145. Grand Rapids: Baker Academic, 2004.

Fee, Gordon D. Exegese van Het Nieuwe Testament: Een Praktische Handleiding. Zoetermeer: Boekencentrum, 2007.

Gaikwad, Roger. "A Reconsideration of the Significance of the Death of Jesus Christ in the Context of Religious Plurality." Transformation: An International Journal of Holistic Mission Studies 36, no. 1 (January 2, 2019): 20-28. http://journals.sagepub.com/doi/10.1177/0265378819831844. 
Grant R. Osrborne. "Recent Trend in the Study of the Apocalypse." In The Face of New Testament Studies: A Survey of Recent Research, edited by Scot McKnignt and Grant R. Osborne, 473-504. Grand Rapids: Baker Academic, 2004.

H.G.L. Peels. God En Geweld in Het Oude Testament. Apeldoorn: Theologische Universiteit, 2007.

Jeremy R. Treat. The Crucified King: Atonement and Kingdom in Biblical and Systematic Theology. Grand Rapids: Zondervan, 2014.

John Creswell. Riset Pendidikan: Perencanaan, Pelaksanaan, Dan Evaluasi Riset Kualitatif \& Kuantitatif. Edisi 5. Yogjakarta: Pustaka Pelajar, 2015.

Laszlo Gallusz. The Throne Motif in the Book of Revelation: Profile from the History of Interpretation. New York: Bloomsbury, 2014.

Loren L. Johns. The Lamb Christology of the Apocalypse of John : An Investigation into Its Origins and Rhetorical Force. WUNT,2/167. Tübingen: Mohr Siebeck, 2003.

Morgan, Robert. "Philip Pullman's Jesus and 'Christ' - and God?" The Expository Times (January 8, 2021): 001452462098371. http://journals.sagepub.com/doi/10.1177/0014524620983714.

P.H.R. van Houwelingen. Goddelijk Geweld in Het Nieuwe Testament, of: Hoe Het Geweld Niet Uit God Verdween, n.d. Accessed February 4, 2021. file:///C:/Users/User/Downloads/28299-Artikel Tekst-32877-1-10-20170306.pdf.

Porter, Stanley E., and Kent D. Clarke. "What Is Exegesis? An Analysis of Various Definitions." In Handbook to the Exegesis of the New Testament, edited by Stanley E. Porter, 3-21. Leiden: BRILL, 1997.

Richard Bauckham. The Theology of The Book of Revelation, New Testament Theology. Cambridge: Cambridge University, 1993.

Richrad B. Hays, and Joel B. Green. "The Use of the Old Testament by New Testament Writers." In Hearing the New Testament:Srategies for Interpretation, 122-139. Grand Rapids: William B. Eerdmans, 2010.

Sérgio Monteiro. "The Lion and the Lamb in Revelation 5." Accessed February 4, 2021. file:///E:/ARTIKEL/The_Lion_and_the_Lamb_in_Revelation_5.pdf.

Smith, Kevin Gary. Writing and Research: A Guide for Theological Students. UK: Langham Global Library, 2016.

Strawn, Brent A. "Why Does the Lion Disappear in Revelation 5? Leonine Imagery in Early Jewish and Christian Literatures." Journal for the Study of the Pseudepigrapha 17, no. 1 (September 2007): 37-74. http://journals.sagepub.com/doi/10.1177/0951820707083881.

Verdianto, Yohanes. "Ontologi Kristus dan Hubungannya dengan Soteriologi." EPIGRAPHE: Jurnal Teologi dan Pelayanan Kristiani 4, no. 2 (2021): 273-282.

http://www.stttorsina.ac.id/jurnal/index.php/epigraphe/article/view/200. 